Research article

\title{
BILATERAL COMMON CAROTID ARTERY LIGATION IN SHEEP. COULD THESE ANIMALS BE USED AS HUMAN MODELS FOR VASCULAR AND CEREBRAL RESEARCH?
}

\author{
PODLAHA Jiř́1 ${ }^{*}$, SCHWANHAEUSER Kräuff², KADEŘÁBKOVÁ Tereza ${ }^{3}$
}

\begin{abstract}
${ }^{1}$ Department of Surgery, University Hospital Brno Bohunice, Faculty of Medicine, Masaryk University, Brno, Czech Republic; ${ }^{2}$ Department of Preventive Medicine / Public Health, Faculty of Medicine, Masaryk University, Brno, Czech Republic; ${ }^{3}$ Department of Anaesthesiology Resuscitation and Intensive Care Medicine, University Hospital Brno Bohunice, Brno, Czech Republic.
\end{abstract}

(Received 19 February, Accepted 07 June 2017)

Experimental animals are still used in today's medicine to understand better physiological or pathological processes, or to develop, for example better vascular prostheses. For that reason, these animals must show some similarities with humans, from the anatomical to the physiological point of view.

When developing vascular prostheses, we have to evaluate if the graft will react in the expected way and if during experimental research there will be some factors that might influence the proper functioning of vascular prostheses in the human body.

We observed the consequences of bilateral common carotid artery ligation (BCCAL) or Sham operation in seventeen healthy Merinolandschaf / Württemberg sheep, aged between 2 and 4 years, after testing new types of carbon-coated ARTECOR® and ADIPOGRAFT Ra 1vk 7/350 vascular prostheses. After the follow-up period the prostheses were extirpated, so the blood supply was provided from the vertebral arteries.

Sheep in both groups were not sacrificed, but were observed for 18 months. After the observation period all sheep showed no physical or neurological changes and all are still alive. Animal responses to BCCAL are different, depending on the animal species, age, and condition. In sheep, bilateral blocking of the blood flow in the carotid bed seems to be conceivable since the brain was sufficiently supplied with blood from the vertebral arteries.

Key words: bilateral common carotid artery ligation (BCCAL), circle of Willis, common carotid artery, sheep survival, Shechita, Dhabihah, Kosher or Halal quality meat

\section{INTRODUCTION}

Is sheep able to survive bilateral ligation of the common carotid artery (BCCAL)?

This question arose as a secondary issue during the experimental assessment of the new type of vascular prostheses (carbon-coated ARTECOR ${ }^{\circledR}$ and ADIPOGRAFT Ra

*Corresponding author: e-mail: Podlaha.Jiri@fnbrno.cz 
1vk 7/350 with Adiponectin) developed at the Knitting Research Institute, a. s. Brno, Czech Republic. The aim of this study was to compare the consequences of bilateral common carotid artery ligation in sheep with those observed in humans, in order to determine if sheep are the ideal animal model for cerebrovascular experimental surgery, as other animals are used for other types of experimental surgeries due to their similarities with humans [1].

Experimental and model animals have been used, by the Greek physician and surgeon Claudius Galenus (129-200 AD), and later by William Harvey (1578-1658 AD) [1]. Nowadays rats, mice, guinea pigs, rabbits, cats, dogs, sheep, pigs, monkeys, are used for surgical / vascular training [2-4], as well as experimental animals [1,5-13]. They are chosen due to their availability, handling, anatomical / physiological similarity with human beings, adaptability to physiological changes, and from the vascular point of view, due to the vessel caliber and the ability to model human responses $[1,5-8,12]$.

Despite similarities to the human anatomy, animal models are unable to reproduce exactly the complex physiological human features [1,5-8,13-18].

Sheep are commonly used as animal models in vascular prosthetic research, mainly for carotid artery, and for many years they have served as the gold standard for cardiovascular bioprosthetic evaluation studies $[1,5-8,13,15,18]$. Their acquisition cost is low, they are easy to maintain, and their anatomical properties (long necks for easy and simple surgical access for vascular prostheses implantation / explantation and their carotid arteries have a similar diameter to those observed in humans) are suitable for vascular prostheses implantation and monitoring [1,5,6,8,11,12].

Sheep coagulation is very similar to humans in comparison to dogs or pigs [1,5], despite the fact that sheep have a higher number of thrombocytes than most species used as experimental animals, having a tendency to hypercoagulation [1]. It was proved that PT, APT'T, activated coagulation time, thrombocyte counts and their aggregation are not influenced neither by anesthesia nor by surgery, except for heparin administration [1,19-20].

From the vascular anatomical, hemodynamic and hematological point of view, humans and sheep differ as presented in Table 1 [1] and Table 2 [1]:

Table 1. Common carotid artery anatomical and physiological differences between human and sheep

\begin{tabular}{lcccc}
\hline & $\begin{array}{c}\text { Diameter } \\
(\mathbf{m m})\end{array}$ & $\begin{array}{c}\text { Mean flow } \\
(\mathbf{m L} / \mathbf{m i n})\end{array}$ & $\begin{array}{c}\text { Mean velocity } \\
(\mathbf{c m} / \mathbf{s})\end{array}$ & $\begin{array}{c}\text { Mean WSS } \\
\left(\mathbf{d y n e s} / \mathbf{c m}^{\mathbf{2}}\right)\end{array}$ \\
\hline Human $^{1,34}$ & $6.5-7.0$ & $455-483$ & $22.3-24.4$ & 7.8 \\
Sheep $^{1}$ & $5.6-7.2$ & 325 & 16.8 & 8.4 \\
\hline
\end{tabular}

All values are expressed as mean or range 
Table 2. Haemodynamic and haematological differences between human and sheep

\begin{tabular}{lccccccc}
\hline & SBP & DBP & HR & TBV & $\begin{array}{c}\text { RCB } \\
\left(\times 10^{9} / \mathbf{m L}\right)\end{array}$ & $\begin{array}{c}\text { Plt } \\
\left(\times 10^{9} / \mathbf{m L}\right)\end{array}$ & $\begin{array}{c}\text { WBC } \\
\left(\times 10^{9} / \mathbf{m L}\right)\end{array}$ \\
\hline Human ${ }^{1,34}$ & $126 \pm 14$ & $79 \pm 10$ & $70 \pm 14$ & 80 & $4.8-5.4$ & $265 \pm 135$ & $7.4 \pm 3.4$ \\
\hline Sheep 1 & 140 & 90 & $95 \pm 24$ & 58 & $10.0-13.0$ & $550 \pm 250$ & $8 \pm 4$ \\
\hline
\end{tabular}

SBP - systolic blood pressure ( $\mathrm{mm} \mathrm{Hg}$ ); DBP - diastolic blood pressure ( $\mathrm{mm} \mathrm{Hg}) ; \mathrm{HR}$ - heart rate (beats / min); TBV - total blood volume $(\mathrm{mL} / \mathrm{Kg})$; RCB - red blood cell count; Plt, platelet count; WBC - white blood cell count. All values are expressed as mean \pm standard deviation or range.

Anatomical overview. Human brain vascular supply: The human brain is supplied in 80$85 \%$ by the two internal carotid arteries and in $15-20 \%$ by the two vertebral arteries $[21,22]$. Both vertebral arteries merge to become the basilar artery before entering the so-called circle of Willis together with both internal carotid arteries. The circle of Willis provides collateral blood flow to the brain. The right and left vertebral arteries branch off the right and left subclavian arteries while the right and left carotid arteries arise from the right and left common carotid arteries [21,22]. Blood is then taken into the brain by the basilar artery which gives off the right and left posterior cerebral arteries. Communicating arteries complement the circle of Willis and then branch off the anterior, medial and posterior arteries. The posterior communicating artery is given off as a branch of the internal carotid artery just before it divides into its terminal branches: the anterior and middle cerebral arteries. Furthermore, the anterior cerebral artery forms the anterolateral portion of the circle of Willis, while the middle cerebral artery does not contribute to the circle of Willis [21]. The importance of the circle of Willis relies on collateral circulation to supply the brain in the case that the main arteries stenose or occlude, so the blood flow from other arteries can maintain brain perfusion [23]. It is important to state that the entire brain blood supply comes from these arteries.

Sheep brain vascular supply: the circle of Willis is observed in mammals but its supply and flow volumes might vary among different species [15,24-27]. This is an important fact at the time of experimentation, because a stenosed or ligated artery might have different consequences. [15,24-27]. In sheep, the brain is supplied as in humans by two carotid and two vertebral arteries [15,24-27]. The internal carotid arteries arise from the common carotid arteries. Both penetrate the skull at the Fissura sphenopetrosa and end up at the rete mirabile epidurale rostrale. At its caudal part, the branches of the vertebral arteries, condillary artery, and the medial meningeal artery from the occipital artery enter bilaterally. The rete epidurale has important connections with the maxillary artery [25,27].The circle of Willis is formed by the cerebral carotid arteries, which caudally end as the Arteria spinalis vertebralis [24,26,27]. The vertebral arteries arise from the Truncus costocervicalis and run cranially through the Canalis transversarium up to the third and second vertebrae. On its way to the neck it gives off the Ramus spinalis which passes through the foramen intervertebrale into the canalis spinalis. Its branch, 
ramus medullaris, goes into the subarachnoideal space and here it joins the $A$. spinalis ventralis $[24,25,27]$. Between the second and the third vertebrae, the $A$. vertebralis splits into a thick lateral stem, which initially runs through the foramen transversarium axialis, then continuing through the foramen vertebrale laterale it pierces the canalis spinalis where it joins the strong intravertebral stem $[24,25,27]$. This artery together with the rami spinales and in the skull with the branches of the Arteria maxillaris (in foetuses also with the $A$. carotis interna) forms the epidural network. The medial branch of the $A$. vertebralis anastomoses to its contralateral part and once it passes the atlas, it splits into a medial final branch, which it joins to its contralateral branch, or forms with it a network which opens into the rete mirabile caudale on the skull base. In most cases these are connected to the A. condylaris [25]. Baldwin and May studied the brain arterial supply in sheep too [28-31]. They proved on latex colored vessels, connections between $A$. vertebralis and $A$. occipitalis, so-called anastomosis occipito-vertebralis. An interesting fact is that these connections are double in sheep, differing with a single one in the rest of the species [28-31]. These anastomoses are designated by Ellenberger and Baum as connecting branches from the lateral final branch of the A. vertebralis [25]. Thus, not only with its final branches supplies the rete mirabile rostrale from its caudal part, but the already described connections provide sufficient blood flow to the $A$. occipitalis. In this way the blood is also provided to the rostral part of the $A$. carotis communis and through the $A$. carotis externa to the $A$. maxillaris [27].

Physiology overview. Cerebral oxygen consumption is around 20\% (about $3.3 \mathrm{ml}$ $/ 100 \mathrm{~g} / \mathrm{min}$ ) of total oxygen consumption of the organism. The highest blood flow is in the grey matter (about four times higher than in the white matter) [32]. Almost $60 \%$ of the cerebral oxygen consumption is spent on nervous tissue functions (electrophysiological functions), such as repolarization - polarization activities. The rest $40 \%$ of the oxygen is needed to maintain cerebral cell homeostasis [32]. The functional association of cerebral metabolism and cerebral blood flow is based on humoral reactions (calcium, potassium ions, and adenosine) via changes in cerebral vascular tone [32]. Changes in partial pressure of $\mathrm{CO}_{2}$ in arterial blood directly influence the cerebral blood flow. On the other hand, partial pressure of $\mathrm{O}_{2}$ in arterial blood influences the cerebral blood flow directly only in the case of a substantial decrease. The blood flow value of about $20 \mathrm{ml} / \mathrm{min} / 100 \mathrm{~g}$ of tissue is critical not only for cerebral functions, but also for the survival of cerebral tissue. In the case of an occlusion of a cerebral artery, cerebral perfusion takes place via the circle of Willis. A certain role is played here also by collateral perfusion through reversal flow in the ophthalmic artery [32]. Human cerebral perfusion needs $750 \mathrm{ml}$ of blood per minute, which represents the $14-15 \%$ of the total cardiac output under basal conditions. Under resting conditions brain metabolism is about $7^{1 / 2}$ times higher than the average metabolism in the rest of the body [34]. The density of the blood capillaries in the brain is greatest where the metabolic needs are greatest. In humans, the overall metabolic rate of the grey matter is about four times higher than that of white matter [24]. In the brain at least three different metabolic factors have potent effects in 
controlling cerebral blood flow. These are carbon dioxide concentration, hydrogen ion concentration and oxygen concentration [32]. Several experiments with animal models to simulate cerebral ischaemia have been described [35-38], including those using sheep [39-42]. One of the most serious complications of abnormal cerebral hemodynamics is the development of brain oedema. Because the brain is encased in a rigid chamber (the cranium), the accumulation of edema fluid compresses the blood vessels, with eventual depression of blood flow and destruction of brain tissue. Carotid ligation per se reduces the inflow pressure. Brain edema has been frequently observed in patients with severe cerebral infarction [43], as well as in animals with experimental infarction caused by arterial occlusion [44].

Bilateral ligation of common carotid artery overview. Surgical arterial ligation has been performed on humans as a hemostasis method since it was first reported by Claudius Galenus (129-200 AD), and then reintroduced by the French surgeon Ambroise Paré (1510-1590 AD) [45-47]. Paré is claimed to have performed the first carotid artery ligation in 1552, being a French soldier with an épée wound his patient; despite the fact the patient was saved he developed aphasia and hemiplegia [45-47]. In 1798, John Abernethy (1764-1831 AD) reported the first common carotid artery ligation as a lifesaving procedure [45]. The naval surgeon David Fleming, performed the first successful common carotid artery ligation. [45,48,49]. The surgeon Astley Cooper (1768-1841) performed the first common carotid artery ligation for a cervical aneurysm, [50] and nowadays the procedure is used to treat cerebral aneurysms, hemorrhage, tumors, etc. [51-54].

In humans, BCCAL has a mortality rate of around 100\% due to the lack of perfusion that causes a large failure in brain metabolism. However, Lilienthal in 1903 [55] and Catlin in 1960 [56] reported two patients who survived BCCAL.

It is important to take into account that slowly a progressive occlusive disease of the internal carotid or common carotid artery is less dangerous and more common than their sudden occlusion.

Cerebrovascular research experiments, especially those focused on cerebral ischemia, use animal models including sheep to recreate human diseases and determined situations, such as those observed during bilateral ligation of the carotid arteries.

The effects of BCCAL in experimental sheep [28,29,40,57-60] as well as in other experimental animals [37,61-77] have been described by many researchers and can be quite different from those observed in humans [55,56,77-80]. Nevertheless, Bunce concluded that permanent interruption of the carotid and vertebral arteries in dogs is not compatible with life [63].

\section{MATERIAL AND METHODS}

The current study was approved by the Ethical Committee of the University of Veterinary and Pharmaceutical Sciences Brno and followed all protocols according 
to the law. Experimental surgery was performed in accordance with the guidelines for animal research established by the Animal Ethics Committee of the University of Veterinary and Pharmaceutical Sciences Brno (Directive 86/609/EEC on the protection of animals used for experimental and other scientific purposes and ARRIVE Guidelines) [86-88]. In addition, all persons included in this experimental assessment possessed the respective license for animal manipulation on experimental medicine, according to the paragraph 17, article 1, of the law 246/1992 Sb., for animal protection against cruelty.

Seventeen healthy Merinolandschaf / Württemberger sheep, aged between 2-4 years $[81,82]$ and free of infectious diseases, were used as experimental animals to implant the new types of vascular prostheses (ARTECOR ${ }^{\circledR}$ and ADIPOGRAFT Ra 1 vk 7/350). After prostheses explantation the animals were followed up for 18 and 12 months respectively, before being passed on to different farms.

Based on earlier experiments conducted by one of the authors on moufflons and other sheep breeds, the authors assumed that the absence of the carotid bed is not a life threatening condition for these animals $[11,12]$.

All animals were followed up on a daily basis and head researchers were contacted in the case of complications. The animals were euthanized if they presented severe pain or suffering, such as food and water intake difficulties (weight loss $>25 \%$ ), inapetence, abnormal posture or locomotion, weakness, respiratory disorders, vocalization disorders, or severe CNS signs during the follow up period [82,83].

\section{RESULTS}

After simultaneous bilateral carotid artery ligation (BCCAL) all seventeen sheep were followed up and their progress was recorded as presented in Table 3.

After 18 months follow-up in the ARTECOR ${ }^{\circ}$ group (8 sheep), and 12 months in the ADIPOGRAFT Ra $1 \mathrm{vk}$ 7/350 group ( 9 sheep), all sheep stayed alive and so far they have shown no impairments (physical or behavioral).

Post-operative complications were observed during the first two months in 2 sheep of the ARTECOR ${ }^{\circledR}$ group and during the first month in 3 sheep of the ADIPOGRAFT Ra 1 vk 7/350 group.

In the both groups, we did not observe visual deficits, hemiparesis, paralysis, complications to adapt to environmental changes (hypothermia), drowsiness, defecation or urination, or long-term cognitive impairment. However, motoric deficiencies around their jaw were observed in 3 sheep which in turn showed eating and behavioral

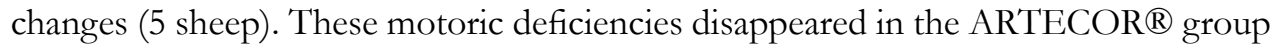
on the $33^{\text {rd }}$ day while in the ADIPOGRAFT Ra $1 \mathrm{vk}$ 7/350 group, disappeared on the day after the BCCAL. Only one sheep expressed apathy for almost 38 days after the surgical procedure, despite normal food intake, from day 12. 
Table 3. Post-operative 18 months follow-up after simultaneous bilateral carotid artery ligation

\begin{tabular}{|c|c|c|c|c|c|c|c|c|}
\hline ARTECOR® & $\begin{array}{c}1 \\
\text { day }\end{array}$ & $\begin{array}{c}1 \\
\text { week }\end{array}$ & $\begin{array}{c}1 \\
\text { month }\end{array}$ & $\begin{array}{c}2 \\
\text { months }\end{array}$ & $\begin{array}{c}3 \\
\text { months }\end{array}$ & $\begin{array}{c}6 \\
\text { months }\end{array}$ & $\begin{array}{c}12 \\
\text { months }\end{array}$ & $\begin{array}{c}18 \\
\text { months }\end{array}$ \\
\hline Still alive & 8 & 8 & 8 & 8 & 8 & 8 & 8 & 8 \\
\hline Signs of paresis or plegia & 0 & 0 & 0 & 0 & 0 & 0 & 0 & 0 \\
\hline Motoric deficiencies & $1^{\mathrm{d}}$ & $1^{\mathrm{d}}$ & $1^{\mathrm{d}}$ & 0 & 0 & 0 & 0 & 0 \\
\hline Amaurosis & 0 & 0 & 0 & 0 & 0 & 0 & 0 & 0 \\
\hline Circling or rotational movements & 0 & 0 & 0 & 0 & 0 & 0 & 0 & 0 \\
\hline Convulsions & 0 & 0 & 0 & 0 & 0 & 0 & 0 & 0 \\
\hline Signs of brain oedema & 0 & 0 & 0 & 0 & 0 & 0 & 0 & 0 \\
\hline Behavioural changes & $2^{\mathrm{d}, \mathrm{f}}$ & $2^{\mathrm{d}, \mathrm{f}}$ & $2^{\mathrm{d}, \mathrm{f}}$ & $1^{\mathrm{f}}$ & 0 & 0 & 0 & 0 \\
\hline Eating changes & $2^{\mathrm{d}, \mathrm{f}}$ & $2^{\mathrm{d}, \mathrm{f}}$ & $1^{\mathrm{d}}$ & 0 & 0 & 0 & 0 & 0 \\
\hline ADIPOGRAFT Ra 1vk 7/350 ® & $\begin{array}{c}1 \\
\text { day }\end{array}$ & $\begin{array}{c}1 \\
\text { week }\end{array}$ & $\begin{array}{c}1 \\
\text { month }\end{array}$ & $\begin{array}{c}2 \\
\text { months }\end{array}$ & $\begin{array}{c}3 \\
\text { months }\end{array}$ & $\begin{array}{c}6 \\
\text { months }\end{array}$ & $\begin{array}{c}12 \\
\text { months }\end{array}$ & $\begin{array}{c}18 \\
\text { months }\end{array}$ \\
\hline Still alive & 9 & 9 & 9 & 9 & 9 & 9 & 9 & - \\
\hline Signs of paresis or plegia & 0 & 0 & 0 & 0 & 0 & 0 & 0 & - \\
\hline Motoric deficiencies & $2^{a, c}$ & $2^{a, c}$ & $2^{a, c}$ & 0 & 0 & 0 & 0 & - \\
\hline Amaurosis & 0 & 0 & 0 & 0 & 0 & 0 & 0 & - \\
\hline Circling or rotational movements & 0 & 0 & 0 & 0 & 0 & 0 & 0 & - \\
\hline Convulsions & 0 & 0 & 0 & 0 & 0 & 0 & 0 & - \\
\hline Signs of brain oedema & 0 & 0 & 0 & 0 & 0 & 0 & 0 & - \\
\hline Behavioural changes & $3^{\mathrm{a}, \mathrm{c}, \mathrm{i}}$ & $2^{a, c}$ & $2^{a, c}$ & 0 & 0 & 0 & 0 & - \\
\hline Eating changes & $3^{a, c, i}$ & $3^{a, c, i}$ & $2^{a, c}$ & 0 & 0 & 0 & 0 & - \\
\hline
\end{tabular}

ARTECOR ${ }^{\circledR}$ group (eight sheep) - Sheep a; sheep b; sheep c; sheep d; sheep e; sheep f; sheep g; sheep h. ADIPOGRAFT Ra 1 vk 7/350 group (nine sheep) - Sheep a; sheep b; sheep c; sheep d; sheep e; sheep f; sheep g; sheep h; sheep i.

Animals regained consciousness promptly after the surgical procedure. None of the sheep showed seizures, anxiety or depression. There were no significant changes in the respiratory pattern as well. After 40 days follow-up no complications were observed in any of the experimental animals.

\section{DISCUSSION}

Large experimental animals are usually used to develop new surgical methods, whereas small experimental animals are more used to understand the mechanisms of disease 
[87]. Before humans are subjected to a clinical trial - for the purpose of developing a new vascular prosthesis - it is necessary to assess rheological and immunological reactions to the prosthesis in animals, in vivo. It is still not possible to replace these experiments with in vitro methods. Therefore, it is still important to use animals in clinical trials.

One important fact to be taken into account when comparing / extrapolating the obtained results in experimental animals and those observed in humans in a daily clinical practice is the fact that these animals are usually young and healthy without any co-morbidities, at least those one observed in humans. There are many anatomical, physiological, immunological, metabolic, pharmacological similarities and differences among experimental animals and humans [1,5-8], but other aspects, such as genetic homogeneity, availability, costs of maintenance, post-operative care needed, public and institutional acceptability, help to decide whether to choose an animal as a human model or not $[1,5]$. For carotid artery research and assessment of vascular prostheses, sheep are mostly chosen due to their similarities to human carotid arteries, such as behaviour of the arterial bed, carotid length and accessibility, endothelisation at the anastomosis site, and carotid artery diameter similar to humans, being around 4 to 6 $\mathrm{mm}[1,5]$.

In the current study on experimental animals, clinical symptoms described by Cho et al [64], such as hemiparesis, circling movements, seizures and / or ptosis were not observed.

These experimental results suggest cerebrovascular protection (changes in cerebral flow after bilateral common carotid artery ligation - BCCAL) can be expected in sheep following bilateral common carotid artery ligation. Probably the sheep age influenced the relative resistance (tolerance) to ischemia $[74,88]$. This fact might indicate that in sheep there is a more significant collateral blood supply to the brain than in humans and thus adaptations occurred after BCCAL increased brain tolerance to hypoxia.

One of the reasons why sheep survived BCCAL might be explained by the occipitovertebral arteries which in turn are connected to the external carotid arteries, eventually reaching the Rete mirabilis and the circle of Willis [1,15,28-31,89].

The occlusion / ligation of both CCA increases the blood flow in the vertebral arteries. [1,28-31,89]. Linzell and Waites described that the occipital arteries carry vertebral blood to the carotid artery system when both carotid arteries are occluded / ligated, and this is caused by the reversal of blood flow in a way that the cephalic structures and the entire brain are supplied through the external carotid arteries and the circle of Willis. In other words, after BCCAL the sheep brain is supplied by the vertebral circulation through the occipito - vertebral anastomosis reaching the brain via the carotid rete and, this mechanism is effective when the carotid sinus nerves are intact $[57,60,61,65]$.

Andersson and Jewell noted that under normal conditions vertebral artery blood supplies only the spinal cord and medulla, but during carotid artery occlusion, a 
reversal flow occurs in the occipital artery, and vertebral blood reaches the entire brain through the external carotid arteries via the carotid rete and the circle of Willis. Thus, the vertebral and spinal blood supplies are able to maintain brain perfusion needs [61]. Physiological blood flow in sheep's basilar artery is away from the circle of Willis [15,90-93].

One important difference between some mammals and humans consists in the rete mirabile. According to Itoyama, these structures in mammals might provide brain protection against overheating and regulate blood pressure and flow of cerebral circulation. In humans it is anomalous and not seen during any developmental stage [94].

Baldwin and Bell observed that BCCAL in sheep may cause EEG changes depending on the severity of brain ischemia, such as slow rhythmic activity. They noted that the ventral spinal artery is able to supply the brain in order to maintain electrical activity in the cortex. In the case both common carotid and vertebral arteries are ligated / occluded, complete brain ischemia will be observed [58,59].

Responses to bilateral occlusion / ligation of the common carotid arteries are different among species [66,70,73], for example, in dogs they show less severity than in humans, proving more collateral brain blood supply [66,95], whereas responses in rats and baboons were more similar to human beings (i.e., retinal or auditory damages; cognitive impairment; some patients had no neuronal deficits unless were exposed to increased metabolic demands during stress; hypoxia or hypotension) $[62,70,72,73,76]$.

Reactions of humans to common carotid artery blood flow blockage are different [37], but when they are bilateral the consequences are fatal with the exceptions of the cases described by Lilienthal in 1903 [55] and Catlin in 1960 [56]. These reactions depend on blood supply failure compensation via the circle of Willis in the brain and also on further factors, e.g. overall condition of the cardiovascular system, etc. The key element making the circle of Willis very effective is its design, because the arteries contained in it are arranged in a looping pattern, allowing a complex system of redundancy built into the blood flow $[15,91,92]$. The circle of Willis significantly helps to prevent certain circulatory conditions from developing within the brain, but several conditions such as thrombosis, bleeding or other cerebral vessels abnormalities, may have devastating consequences. We have to think about the fact that this circle is often not complete and just one third of the population has it complete [91-93].

Nowadays the majority of medical treatments and techniques used in patients were developed and tested in animals, however, as Kaste and Pound described these animal experiments frequently fail to replicate human diseases [96-97]. The difficulty to extrapolate animal experimental results to humans has been described in the $11^{\text {th }}$ Century by the Persian polymath Ibn-Sina / Avicena (980-1037) $[87,88]$, and by the English poet Alexander Pope (1688-1744) in his quote "the proper study of mankind is man", published in 1733-1734 in the An Essay on Man [98,99]. 
At the time of comparing animal model results with those observed in humans we must bear in mind co-morbidities present in humans and not in animals, and different underlying disease / symptoms mechanisms.

The ideal experimental animals to model human diseases / symptoms are those which mimic humans from the physiological (metabolic) and pathophysiological point of view, in a way that the obtained results from these experiments might be comparable with those in humans [1].

In order to understand human diseases, different experimental animal models have been designed. However, due to significant differences between animal species and humans (i.e., anatomical, physiological, immunological, metabolic, genetic, etc.) the obtained results might be different when translating them to humans. This fact is of importance when considering successful treatments in animals, because those may fail in humans, due to animal adaptability and resistance to biological and physiological changes [100].

These translation variations might be enhanced in many studies by poor methodological design quality, lack of similarity between clinical trials and animal models, thus causing bias when representing adequately human diseases / symptoms [14].

Systematic reviews will provide available evidence data and insights into experimental animal limitations, reducing the number of unnecessary and simultaneous experiments (principles of replacement, reduction and refinement), improving their methodology and validity and so their quality [14,97,100-102].

Additional issues came to surface with the obtained results and these are the Shechita, and the Dhabihah ((i.e. Kosher or Halal quality respectively). In our case, all sheep survived the absence of carotid artery blood supply, which implies animal suffering during such ritual sacrifices. Here, the importance of the vertebral arteries and the rete mirabilis epidurale for animal brain perfusion during these Jewish and Muslim ritual sacrifices. It was noted that after both carotid arteries were cut, vital EEG activity was present in these animals, showing prolonged consciousness, and thus raising concerns against such ritual sacrifices [103-104]. Scientific literature concerning brain blood supply, animal pain, time to lose consciousness and subsequent brain failure is contradictory, having variations in the case of the same species and experiments [103-110]. For example, according to Daly et al, contribution of the vertebral arteries to the total brain blood flow is different between animal species [106,107], whereas Nangeroni and Kennett stated that contribution of the vertebral arteries is not that important [104].

It is already known that BCCAL in humans has a mortality rate of almost $100 \%$. The relevance of animal models to human health is questioned because of the differences between species. It is already known that experimental animal models cannot mimic human responses properly. 
Our study adds to this topic the fact that sheep can survive without carotid artery supply, which is nearly always lethal in humans. However we acknowledge several limitations of the current study. First, a relatively small number of used animals and the exploratory nature of this study may decrease its reliability and statistical significance. Second, we did not perform any electroencephalograms, cognitive tests, measures of blood flow, laboratory or diagnostic examinations during the follow up period in order to obtain detailed information on sheep reaction to BCCAL. We just relied on clinical observation. Nevertheless, the strength of our study consist in the fact that there were no variations in the animal selection, preoperative and post-operative procedures. The follow-up period was established according to human symptoms appearance and their latency.

We recommend further studies with particular attention on cerebrovascular research, in order to decide which experimental animal is the most convenient to be used.

\section{CONCLUSION}

Animal models used for human research still have relevant importance, despite their limitations. In the current experiment all animals survived the BCCAL procedure without apparent cerebrovascular damage, so it can be assumed that the hemodynamic effects of bilateral common carotid artery ligation in sheep are life compatible, in contrast to that observed in humans. Thus, as in previous experiments the author carried out, the results suggest that using sheep for cerebrovascular research could not be appropriate due to their ischemic tolerance, collateral vessels distribution.

The important issue at the animal model choice is a good methodological study design based on the differences and similarities shown with humans, which helps reducing systematic and random errors. It is important to bear in mind that there is no universal method that could recreate human diseases perfectly.

\section{Acknowledgements}

This study was supported by the Ministry of Industry and Trade of the Czech Republic (Project: 2A - 1TP1 / 122).

The authors would like to thank: University of Veterinary and Pharmaceutical Sciences Brno, for their technical contributions to the study.

\section{Authors' contributions}

PJ participated in design of the study, coordinated the study, carried out experimental surgery on sheep, participated on sheep follow-up, helped with data acquisition and posteriorly analysis and interpretation, helped with manuscript drafting. SK participated in design of the study, participated on sheep follow-up, helped with 
data acquisition and posteriorly analysis and interpretation, helped with manuscript drafting. KT participated on sheep follow-up, helped with data acquisition and helped with manuscript drafting. All authors read and approved the final manuscript.

\section{Declaration of conflicting interests}

The author(s) declared no potential conflicts of interest with respect to the research, authorship, and/or publication of this article.

\section{RFERENCES}

1. Byrom MJ, Bannon PG, White GH, Ng MKC: Animal models for the assessment of novel vascular conduits. J Vasc Surg 2010, 52(1):176-195.

2. Toledo-Pereyra LH: The ethics of surgical research. J Invest Surg 2003, 16(3):119-121.

3. Aboud E, Suarez CE, Al-Mefty O, Yasargil MG: New alternative to animal models for surgical training. Altern Lab Anim 2004, 32(suppl 1):501-07.

4. Peirovi H, Farnia P, Bahrami A, Mohsenifar Z, Kashani BA, Ghanavi JE: Modified sleeve anastomosis in large muscular arteries of sheep. Eur J Vasc Endovasc Surg 2005, 30(4):381385.

5. Conn PM (ed): Animal models for atherosclerosis, restenosis, and endovascular aneurysm repair. In: Sourcebook of models for biomedical research. Totowa, New Jersey, USA: Humana Press; 2008, 3-27, 355-397.

6. Swartz DD, Andreadis ST: Animal models for vascular tissue-engineering. Curr Opin Biotechnol 2013, 24(5):916-925.

7. Zaragoza C, Gomez-Guerrero C, Martin-Ventura JL, Blanco-Colio L, Lavin B, Mallavia B, Tarin C, Mas S, Ortiz A, Egido J: Animal models of cardiovascular diseases. J Biomed Biotechnol 2011, 497841.

8. Narayanaswamy M, Wright KC, Kandarpa K: Animal models for atherosclerosis, restenosis and endovascular graft research. J Vasc Interv Radiol 2000, 11(1):5-17.

9. Syedain ZH, Meier LA, Lahti MT, Johnson SL, Tranquillo RT: Implantation of completely biological engineered grafts following decellularization into the sheep femoral artery. Tissue Eng Part A 2014, 20(11-12):1726-1734.

10. Ao PY, Hawthorne WJ, Vicaretti M, Fletcher JP: Development of intimal hyperplasia in six different vascular prostheses. Eur J Vasc Endovasc Surg 2000, 20(3):241-249.

11. Trantina-Yates A, Weissenstein C, Human P, Zilla P: Stentless bioprosthetic heart valve research: sheep versus primate model. Ann Thorac Surg 2001, 71 (5 suppl):S422-427.

12. Podlaha J, Dvořák M, Věra Žižková, Dvořák R, Kabeš R, Jelínek M, Veselý K: Experimental assessment of a new type of carbon-coated ARTECOR ${ }^{\circledR}$ vascular prosthesis in sheep. Acta Vet Brno 2009, 78 (1):115-120.

13. Goodman SL: Sheep, pig, and human platelet-material interactions with model cardiovascular biomaterials. J Biomed Mater Res 1999, 45(3):240-250. 
14. Perel P, Roberts I, Sena E, Wheble P, Briscoe C, Sandercock P, Macleod M, Mignini LE, Jayaram P, Khan KS: Comparison of treatment effects between animal experiments and clinical trials: systematic review. BMJ 2007, 334(7586):197. Epub.

15. Ashwini CA, Shubha R, Jayanthi K: Comparative anatomy of the circle of Willis in man, cow, sheep, goat and pig. Neuroanatomy 2008, 7:54-65.

16. Lee RM: Morphology of cerebral arteries. Pharmacol Ther 1995, 66(1):149-173.

17. McDonald DA, Potter JM: The distribution of blood to the brain. J Physiol 1951, 114(3):356-371.

18. Haouzi P, Chenuel B, Chalon B, Braun M, Bedez Y, Tousseul B, Claudon M, Gille JP: Isolation of the arterial supply to the carotid and central chemoreceptors in the sheep. Exp Physiol 2003, 88(5):581-594.

19. Tilman P, Carson SN, Talken L: Platelet function and coagulation parameters in sheep during experimental vascular surgery. Lab Anim Sci 1981, 31(3):263-267.

20. Foley SR, Solano C, Simonova G, Spanevello MM, Bird RJ, Semple JW, Jackson DE, SchiblerA, Fraser JF, Fung YL: A comprehensive study of ovine haemostasis to assess suitability to model human coagulation. Thromb Res 2014, 134(2):468-473.

21. Standring S (editor-in-chief): Vascular supply and drainage of the brain. In: Gray's Anatomy. The anatomical basis of clinical practice. $40^{\text {th }} \mathrm{ed}$. Edinburgh, Scotland, UK: Churchill Livingstone Elsevier; 2008, 446-460.

22. Kapoor K, Singh B, Dewan J: Variations in the configuration of the circle of Willis. Anat Sci Int 2008, 83(2): 96-106.

23. Boorder M, van der Grond J, van Dongen AJ, Klijn CJ, Jaap Kappelle L et al: Spect measurements of regional cerebral perfusion and carbondioxide reactivity: Correlation with cerebral collaterals in internal carotid artery occlusive disease. J Neurol 2006, 253(10):12851291.

24. Purves MJ: Some aspects of the anatomy of cerebral blood vessels. In: The physiology of the cerebral circulation. Cambridge, UK: Cambridge University Press; 1972, 1-10, 69-100, 156-172.

25. Grau H: Der Kreislaufapparat In: Ellenberger W, Baum H: Handbuch der vergleichenden Anatomie der Haustiere. $18^{\text {th }}$ ed. Berlin, Germany: Springer-Verlag; 1943, 629-644, 662-669.

26. I.C.V.G.A.N: Angiologia. In: Nomina Anatomica Veterinaria. $5^{\text {th }}$ ed. Hannover, Columbia, Gent, Sapporo: Editorial Committee I.C.V.G.A.N; 2005, 78-85.

27. Waibl H, Sinowatz F: Kreislaufapparat und Lymphatisches System. In: Nickel R, Schummer A, Seiferle E: Lehrbuch der Anatomie der Haustiere Band III - Kreislaufsystem, Haut und Hautorgane. $4^{\text {th }}$ ed. Stuttgard, Germany: Parey Verlag; 2004, 104-120.

28. Baldwin BA, Bell FR: Blood flow in the carotid and vertebral arteries of the sheep and calf. J Physiol 1963, 167:448-462.

29. Baldwin BA, Bell FR: The anatomy of the cerebral circulation of the sheep and ox. The dynamic distribution of the blood supplied by the carotid and vertebral arteries to cranial regions. J Anat 1963, 97(2):203-215.

30. May NDS: Arterial anatomoses in the head and neck of the sheep. J Anat 1967, 101(2):381387.

31. May NDS: Experimental studies of the collateral circulation in the head and neck of sheep (Ovis aries). J Anat 1968, 103(1):171-181. 
32. Guyton A, Hall J: Cerebral blood flow, the cerebrospinal fluid and brain metabolism. In: Textbook of medical physiology. $11^{\text {th }}$ ed. Philadelphia, Pennsylvania, USA: Elsevier Saunders; 2006, 761-770.

33. Zarrinkoob L, Ambarki K, Wahlin A, Birgander R, Eklund A, Malm J: Blood flow distribution in cerebral arteries. J Cereb Blood Flow Metab 2015, 35(4):648-654.

34. Hibbard L, McGlone JS, Davis DW, Hawkins RA: Three-dimensional representation and analysis of brain energy metabolism. Science 1987, 236(4809):1641-1646.

35. Casals JB, Pieri NC, Feitosa ML, Ercolin AC, Roballo KC, Barreto RS, Bressan FF, Martins DS, Miglino MA, Ambrósio CE: The use of animal models for stroke research: a review. Comp Med 2011, 61(4):305-313.

36. Graham SM, McCullough LD, Murphy SJ: Animal models of ischemic stroke: Balancing experimental aims and animal care. Comparative Med 2004, 54(5):486-496.

37. Hossmann KA: Animal models of cerebral ischemia. 1 Review of literature. Cerebrovasc Dis 1991, 1(Suppl 1):2-15.

38. Traystman RJ: Animal models of focal and global cerebral ischemia. ILAR J 2003, 44(2):8595.

39. Förschler A, Boltze J, Waldmin D, Gille U, Zimmer C: MRI of experimental focal cerebral ischemia in sheep. Rofo 2007, 179(5):516-524.

40. Terlecki S, Baldwin BA, Bell FR: Experimental cerebral ischaemia in sheep. Neuropathology and clinical effects. Acta Neuropathol 1967, 7(3):185-200.

41. Wells AJ, Vink R, Blumbergs PC, Brophy BP, Helps SC, Knox SJ, Turner RJ: A surgical model of permanent and transient middle cerebral artery stroke in the sheep. PLoS One 2012, 7(7):e42157.

42. McClure M, Riddle A, Manese M, Luo NL, Rorvik DA, Kelly KA, Barlow CH, Kelly JJ, Vinecore K, Roberts C, Hohimer AR, Back SA: Cerebral blood flow heterogenicity in preterm sheep: Lack of physiological support for vascular boundary zones in foetal cerebral white matter. J Cereb Blood Flow Metab 2008, 28(5):995-1008.

43. Shaw C, Alvord E, Berry R: Swelling of the brain following ischaemic infarction with cerebral occlusion. Arch Neurol 1959 1:161-177.

44. Teraura T, Meyer J, Sakamoto K: Hemodynamic and metabolic concomitants of brain swelling and cerebral oedema due to experimental infarction. J Neurosurg 1972, 36 (6):728744.

45. Pearce JMS: Historical note on carotid disease and ligation. Eur Neurol 2014, 72(1-2):2629.

46. Robicsek F, Roush TS, Cook JW, Reames MK: From Hippocrates to Palmaz-Schatz, the history of carotid surgery. Eur J Vasc Endovasc Surg 2004, 27 (4):389-397.

47. Thompson JE: Carotid surgery: The past is prologue. J Vasc Surg 1997, 25 (1):131-140.

48. Coley RW: Case of rupture of the carotid artery and wounds of several of its branches, successfully treated by tying the common trunk of the carotid itself. Med Chir J Rev 1817, 3:1-4.

49. Thompson JE: The evolution of surgery for the treatment and prevention of stroke. The Willis lecture. Stroke 1996, 27(8):1427-1434.

50. Cooper A: A case of aneurysm of the carotid artery. Med Chir Trans 1809, 1:1-12.

51. Okamoto Y, Inugami A, Matzuzaki Z, Yokomizo M, Konno A, Togawa K, Kuribayashi R, Ogawa T, Kanno I: Carotid artery resection for head and neck cancer. Surgery 1996, 120(1):54-59. 
52. Konno A, Togawa K Lizuka K: Analysis of factors affecting complications of carotid ligation. Ann Otol Rhinol Laryngol 1981, 90(3):222-226.

53. Kroeker TR, O'Brien JC: Carotid resection and reconstruction associated with treatment of head and neck cancer. Proc (Bayl Univ Med Cent) 2011, 24(4):295-298.

54. Winn HR, Richardson AE, Jane JA: Late morbidity and mortality of common carotid ligation for posterior communicating aneurysms. A comparison to conservative treatment. J Neurosurg 1977, 47(5):727-736.

55. Lilienthal D.: Ligation of both common carotids. Ann Surg 1903, 37(3):443-444.

56. Catlin D: A case of carcinoma of the larynx survival bilateral carotid artery ligation. Ann Surg 1960, 152 (5): 809-814.

57. Linzell JL, Waites GM: The effects of occluding the carotid and vertebral arteries in sheep and goats. J Physiol 1957, 138:P20.

58. Baldwin BA, Bell FR: The effect of temporary reduction in cephalic blood flow on the EEG of sheep and calf. Electroencephalogr Clin Neurophysiol 1963, 15(3):465-473.

59. Baldwin BA, Bell FR: The effect on blood pressure in the sheep and calf of clamping some of the arteries contributing to cephalic circulation. J Physiol 1963, 167:463-479.

60. Waites GM: The influence of the occipito-vertebral anastomoses on the carotid sinus reflex of the sheep. Q J Exp Physiol Cogn Med Sci 1960, 45(3):243-251.

61. Andersson B, Jewell PA: The distribution of carotid and vertebral blood in the brain and spinal cord of the goat. Q J Exp Physiol Cogn Med Sci 1956, 41(4):462-474.

62. Bhattacharjee AK, White L, Chang L, Ma K, Harry GJ, Deutsch J, Rapoport SI: Bilateral common carotid artery ligation transiently changes brain lipid metabolism in rats. Neurochem Res 2012, 37(7):1490-1498.

63. Bunce D: Survival of dogs following section of carotid and vertebral arteries. Proc Soc Exp Biol Med 1960, 103:581-585.

64. Cho JN, Kim SH, Kim KT, Kim Y: Clinical and pathological study after ligation of common carotid artery in the rat. J Korean Neurosurg Soc 1991, 20(12):1069-1075.

65. Chungcharoen D, De Burgh DM, Neil E, Schweitzer A: The effect of carotid occlusion upon the intrasinusal pressure with special reference to vascular communications between the carotid and vertebral circulations in the dog, cat and rabbit. J Physiol 1952, 117(1):5676.

66. Clendenin MA, Conrad MD: Collateral vessel development after chronic bilateral common carotid artery occlusion in dog. Am J Vet Res 1979, 40(9):1244-1249.

67. Eseoglu M, Yilmaz I, Karalar M, Aydin MD, Kayaci S, Gundogdu C, Gunaldi O, Onen MR: The role of sympathectomy on the regulation of basilar artery volume changes in stenoocclusive carotid artery modelling after bilateral common carotid artery ligation: an animal model. Acta Neurochir (Wien) 2014, 156(5):963-969.

68. Farkas E, Luiten PG, Bari F: Permanent bilateral common carotid artery occlusion in the rat: a model for chronic cerebral hypoperfusion-related neurodegenerative diseases. Brain Res Rev 2007, 54(1):162-180.

69. Huang Y, Fan S, Li J, Wang YL: Bilateral common carotid artery occlusion in the rat as a model of retinal ischaemia. Neuroophthalmology 2014, 38(4):180-188.

70. Lavinsky D, Arterni NS, Achval M, Netto CA: Chronic bilateral common carotid artery occlusion: a model for ocular ischemic syndrome in the rat. Graefes Arch Clin Exp Ophthalmol 2006, 244(2):199-204. 
71. Melo MCSC, Gadelha D, Mascena GV, Oliveira TK, Brandt CT: Learning and survival undergoing a permanent bilateral carotid ligation in rats. Acta Cir Bras 2013, 28(2):102-105.

72. Ohta H, Nishikawa H, Kimura H, Anayama H, Moyamoto M: Chronic cerebral hypoperfusion by permanent internal carotid ligation produces learning impairment without brain damage in rats. Neuroscience 1997, 79(4):1039-1050.

73. Oldendorf WH: Trophic changes in the arteries at the base of the rat brain in response to bilateral common carotid artery ligation. J Neuropathol Exp Neurol 1989, 48(5):534-547.

74. Payan HM: Ill-effects of carotid artery ligation: Experimental study on influence of age. Ann Surg 1967, 165(4):544-550.

75. Sarti C, Pantoni L, Bartolini L, Inzitari D: Persistent impairment of gait performances and working memory after bilateral common carotid artery occlusion in the adult Wistar rat. Behav Brain Res 2002, 136(1):13-20.

76. Sengupta D, Harper M, Jennet B: Effect of carotid ligation on blood flow in baboons. 2. Response to hypoxia and haemorrhagic hypertension. J Neurol Neurosurg Psychiatry 1974, 37(5):578-584.

77. Chen L, Shang Y, Sipos E, Saatman KE, Yu G, Toborek M: Novel experimental model for repeated forebrain ischemia-reperfusion. J Exp Stroke Transl Med 2012, 5(1):1-10.

78. Jha AN, Butler P, Lye RH, Fawcitt RA: Carotid ligation: what happens in the long term? J Neurol Neurosurg Psychiatry 1986, 49(8):893-898.

79. Yashon D, Johnson AB, Jane JA: Bilateral internal carotid artery occlusion secondary to closed head injuries. J Neurol Neurosurg Psychiatry 1964, 27:547-552.

80. Maves MD, Bruns MD, Keenan MJ: Carotid artery resection for head and neck cancer. Ann Otol Rhinol Laryngol 1992, 101(9):778-781.

81. Enzler M, Zünd G, Schneider J: A new approach to in vivo testing of vascular grafts. Vasa 1994, 23(3):251-256.

82. Giardino R, Fini M, Rocca M, Nicoli N, Martini L, Giavaresi G, Di Paola MD, Orienti L, Faggioli G, Gargiulo M: In vivo experimental research in vascular surgery. Methodology and current Italian law. Minerva Chir 1995, 50(6):613-619.

83. AVMA (American Veterinary Medical Association): Report of the AVMA. Panel on euthanasia. J Am Vet Med Assoc 1993, 202(2):229-249.

84. Louhimies S: Directive 86/609/EEC on the protection of animals used for experimental and other scientific purposes. ATLA-Altern Lab Anim 2002, 30 (2):217-219.

85. Hooijmans CR, de Vries R, Leenaars M, Curfs J, Ritskes-Hoitinga M: Improving planning, design, reporting and scientific quality of animal experiments by using the gold standard publication checklist, in addition to the ARRIVE guidelines. Brit J Pharmacol 2011, 162:1259-1260.

86. Kilkenny C, Browne WJ, Cuthill IC, Emerson M, Altman DG: Improving bioscience research reporting: the ARRIVE guidelines for reporting animal research. PLoS Biol 2010, 8 (6):1-5. e1000412.

87. Trollope A, Moxon JV, Moran CS, Golledge J: Animal models of abdominal aortic aneurysm and their role in furthering management of human disease. Cardiovasc Pathol 2011, 20(2):114-123.

88. Jackson SJ, Andrews N, Ball D, Bellantuono I, Gray J, Hachoumi L, Holmes A, Latcham J, Petrie A, Potter P, Rice A, Ritchie A, Stewart M, Strepka C, Yeoman M, Chapman K: Does age matter? The impact of rodent age on study outcomes. Lab Anim 2016, [Epub ahead of print]. 
89. Baldwin BA: The anatomy of the arterial supply of the cranial regions of the sheep and ox. Am J Anat 1964, 115 (1):101-118.

90. Daniel PM, Dawes JDK, Prichard MML: Studies of the carotid rete and its associated arteries. Philos Trans R Soc Lond (Biol) 1953, 237: 173-208.

91. Kapoor K, Kak VK, Singh B: Morphology and comparative anatomy of circulus arteriosus cerebri in mammals. Anat Histol Embryol 2003, 32(6):347-355.

92. Kapoor K, Singh B, Dewan LI: Variations in the configuration of the circle of Willis. Anat Sci Int 2008, 83 (2):96-106.

93. Deepthi S, Suseelamma D, Pramod Kumar D, Saradadevi SS, Subhadradevi V: Comparative study of formation of circle of Willis in human and sheep brain. J Anat Soc India 2016, 65 (Suppl 1):S16-S19.

94. Itoyama Y, Kitano I, Ushio Y: Carotid and vertebral rete mirabile in man - case report. Neurol Med Chir (Tokyo) 1993, 33:181-184.

95. Whisnant JP, Millikan CH, Sayre GP, Wakim KH: Collateral circulation to the brain of the dog following bilateral ligation of the carotid and vertebral arteries. Am J Physiol 1956, 186 (2):275-277.

96. Kaste M: Use of animal models has not contributed to development of acute stroke therapies. Stoke 2005, 36(10):2323-2324.

97. Pound P, Ebrahim S, Sandercock P, Bracken MB, Roberts I: Where is the evidence that animal research benefits humans? BMJ 2004, 328(7438):514-517.

98. Bracken MB: Why animal studies are often poor predictors of human reactions to exposure. J R Soc Med 2009, 102(3):120-122.

99. Gold H: The proper study of mankind is the man. Am J Med 1952, 12(6):619-620.

100. Hackam DG, Redelmeier DA: Translation of research evidence from animals to humans. JAMA 2006, 296 (14):1731-1732.

101. Matthews RAJ: Medical progress depends on animal models - doesn't it? J Royal Soc Med 2008, 101(2):95-98.

102. Mignini LE, Khan KS: Methodological quality of systematic reviews of animal studies: a survey of reviews of basic research. BMC Med Res Methodol 2006, 6:10.

103. Newhook JC, Blackmore DK: Electroencephalographic studies of stunning and slaughter of sheep and calves - part 1: The onset of permanent insensibility in sheep during slaughter. Meat Sci 1982, 6 (3):221-233.

104.Nangeroni LI, Kennett PD: The study of the effects of Shechita slaughter on the sheep (Ovis aries). In: An electroencephalographic study of the effect of Shechita slaughter on cortical function in ruminants. New York, USA: Department of Physiology - Veterinary College - Cornell University 1963, 1-17.

105. Rosen SD: Physiological insights into Shechita. Vet Rec 2004, 154 (24):759-765.

106. Daly CC, Kallweit E, Ellendorf F: Cortical function in cattle during slaughter: conventional captive bolt stunning followed by exsanguinations compared with Shechita slaughter. Vet Rec 1988, 325-329.

107.Daly CC, Whittington P: Concussive methods of pre-slaughter stunning in sheep: effects of captive bolt stunning in the poll position on brain function. Res Vet Sci 1986, 41 (3):353-355.

108. Daly CC, Whittington PE: Investigation into the principal determinants of effective captive bolt stunning of sheep. Res Vet Sci 1989, 46 (3):406-408. 
109. Rodriguez P, Velarde A, Dalmau A, Llonch P: Assessment of unconsciousness during slaughter without stunning in lambs. Anim Welf 2012, 21 (S2):75-80.

110. Fuseini A, Wotton SB, Hadley PJ, Knowles TG: The perception and acceptability of preslaughter stunning for Halal production: The views of UK Islamic scholars and Halal consumers. Meat Sci 2017, 123:143-150.

\title{
BILATERALNA LIGATURA A. CAROTIS COMMUNIS OVCE. DA LI SE OVA ŽIVOTINJA MOŽE KORISTITI KAO HUMANI MODEL ZA VASKULARNA I CEREBRALNA ISTRAŽIVANJA?
}

\author{
PODLAHA Jiří, SCHWANHAEUSER Kräuff, KADEŘÁBKOVÁ Tereza
}

U savremenoj medicini eksperimentalne životinje su i dalje u upotrebi u cilju boljeg razumevanja fizioloških i patoloških procesa, ili razvoja savršenijih vaskularnih proteza. Iz ovog razloga, eksperimentalne životinje moraju da imaju u određenoj meri sličnosti sa ljudima, kako sa anatomskog tako sa fiziološkog aspekta.

Prilikom razvoja vaskularnih proteza morali smo da izvršimo procenu da li će graft da reaguje na očekivani način i da li postoje faktori koji mogu da utiču na adekvatno funkcionisanje vaskularne proteze u ljudskom organizmu. Posmatrali smo posledice bilateralne ligature zajedničke karotidne arterije (BCCAL) kod sedamnest zdravih Merino/ Virtenberg ovaca, starosti od 2 do 4 godine, nakon testiranja novog tipa ARTECOR $\mathbb{R}$ i ADIPOGRAFT Ra 1vk 7/350 vaskularnih proteza. Nakon perioda praćenja, proteze su uklonjene, a snabdevanje mozga krvlju su omogućile vertebralne arterije.

Ovce obe grupe nisu bile žrtvovane već su bile u opservaciji tokom narednih 18 meseci. Nakon perioda opservacije nijedna ovca nije pokazala znake fizičkih ili neuroloških promena. Odgovori životinja na BACCAL su bili različiti u zavisnosti od životinjske vrste, starosti i kondicije. Kod ovaca bilateralna blokada protoka krvi u karotidnom koritu izgleda moguća obzirom da je mozak bio dovoljno prokrvljen preko vertebralnih arterija. 